\title{
EFFECT OF TRIETHYLENEMELAMINE (TEM) AND CADMIUM CHLORIDE ON SPERMATOGENESIS IN RABBITS
}

\author{
S. K. PAUFLER AND R. H. FOOTE \\ Tierärztliches Institut der Universität Göttingen, Germany, and \\ Department of Animal Science, Cornell University, Ithaca, New York, U.S.A.
}

(Received 24th Fune 1968)

\begin{abstract}
Summary. Five groups of sexually mature, Dutch-belted male rabbits were studied. Group I consisted of ten controls. Group II (five males) received one injection of $0.2 \mathrm{mg}$ of triethylenemelamine (TEM) $/ \mathrm{kg}$ body weight. Group III (two males) received twice the amount of TEM given to Group II, and Group IV (five males) received five weekly injections of $0.4 \mathrm{mg}$ TEM $/ \mathrm{kg}$ body weight. Group V (five males) received one subcutaneous injection of $0.05 \mathrm{~m}$-mole $\mathrm{CdCl}_{2} / \mathrm{kg}$ body weight. Spermatogonial divisions were inhibited in TEM-treated animals. In Groups II and III, sperm output reached minimal levels 8 to 9 weeks after treatment. Recovery took place within 6 weeks. In Group IV, sperm output was also reduced to minimal levels by the 8th week. Slow recovery was initiated about 15 weeks after the initial TEM injections. Cadmium chloride caused extensive damage and marked atrophy of the testes, so that extra-tubular tissue accounted for about $75 \%$ of the testis. Aspermia was approached within 4 weeks. Little recovery followed during 17 weeks following treatment. The percentage of motile spermatozoa and morphologically normal spermatozoa was markedly reduced in Groups IV and V. All treated groups showed marked changes in the frequency of the eight stages of the cycle of the seminiferous epithelium and depression of fertility. Rapid recovery followed in the TEMtreated groups.
\end{abstract}

\section{INTRODUCTION}

Jackson \& Bock (1955) and Bock \& Jackson (1957) reported that triethylenemelamine (Tretamine, TEM) produced sterile phases in male rats, apparently by acting on epididymal spermatozoa and by affecting spermatogonial divisions. Fox, Jackson, Graig \& Glover (1963) showed that TEM in rabbits reduced sperm output and resulted in temporary sterility. Hampel \& Gerhartz (1965) found that TEM produced chromosome abnormalities in cultured leucocytes, and TEM-induced chromosome anomalies have been associated with lowered fertility and sterility (Cattanach \& Edwards, 1958; Steinberger, Nelson, Boccabella \& Dixon, 1959; Cattanach, 1959; Bateman, 1960). 
Since the extensive research by Paŕízek (1960) on sterilization by cadmium, primarily in the rat, numerous workers have reported similar effects (Gunn, Gould \& Anderson, 1963; Chiquoine, 1964; Mason, Brown, Young \& Nesbit, 1964; Gunn, Gould \& Anderson, 1965). A dramatic but highly variable destruction in rabbit testes was reported by Cameron \& Foster (1963) following cadmium administration.

The present report is a detailed quantitative comparison of the effects of TEM and cadmium upon testicular function, sperm characteristics and fertility of treated rabbits, and the normality of young born to those rabbits.

\section{MATERIALS AND METHODS}

Twenty-eight, sexually mature, Dutch-belted male rabbits, raised under controlled conditions, were trained to serve the artificial vagina (Bredderman, Foote \& Yassen, 1964). Two semen collections from each male on Monday, Wednesday and Friday during a pre-treatment period provided information on semen quality necessary to equalize each group initially on the basis of spermproducing capacity. This schedule was continued throughout the experimental period, resulting in more than 3000 semen collections. Insemination with semen collected just before treatment (Week 0) served as an indication of the initial fertility level of each group.

Ten males were used as controls (Group I). TEM was injected i.v. into five rabbits in a single dose of $0.2 \mathrm{mg} / \mathrm{kg}$ body weight (Group II), into two bucks in a single dose of $0.4 \mathrm{mg} / \mathrm{kg}$ body weight (Group III), and into five rabbits in five weekly injections of $0.4 \mathrm{mg} / \mathrm{kg}$ body weight (Group IV). Cadmium chloride $\left(\mathrm{CdCl}_{2}\right)$ was given s.c. in one dose of $0.05 \mathrm{~m}$-mole $/ \mathrm{kg}$ body weight to five rabbits (Group V).

The number of spermatozoa collected weekly from each rabbit was determined by haemocytometer counts and volume measurements. Losses in the artificial vagina were accounted for by flushing with physiological saline (Foote, 1964).

Semen smears were prepared once a week from each rabbit and stained with aniline blue-crystal violet to investigate sperm morphology. One hundred cells per slide were classified. The progressive motility of spermatozoa was estimated at weekly intervals using freshly collected semen diluted with physiological saline.

Histological evaluation of the testis was done by performing testicular biopsies. The biopsies were taken from males under anaesthesia by the opensurgery technique (Foote \& Koefoed-Johnsen, 1959). Males recovered quickly and uneventfully from the operation, with little effect on the residual testicular material. The biopsies were taken 1 week after the initial treatment and then were repeated at intervals of 4 weeks. The testis to be biopsied was chosen at random but three biopsies were made eventually on each testis. The biopsied tissue was fixed in Bouin's solution, cut at $7 \mu$ and stained with PAS-haematoxylin as described by Swierstra (1962).

The percentage of spermatogonia, primary spermatocytes, round spermatids, and intra- and extra-tubular tissue was calculated from 1500 structures classi- 
fied per animal at each interval sampled. The random hit procedure of Chalkley (1943), facilitated by a specially engraved ocular disc (Greiner \& Co., Bremen 1, Germany) was used to obtain an unbiased estimate of the frequency of each structure. The application of this procedure for the quantitative determination of the population of cell types in testicular tissue has been described previously (Kennelly \& Foote, 1964). Tubules cut at right angles to their long axes were used to measure tubular diameters. Two measurements perpendicular to each other were made with an ocular micrometer on eight tubules per animal per interval. The frequency of the eight stages of the seminiferous epithelium was measured by analysing the cell combinations in cross-sections and classifying the stages in 100 tubules per rabbit, as outlined by Swierstra \& Foote (1963).

To test the fertility of semen collected, 176 females were inseminated artificially with $0.2 \mathrm{ml}$ of the original semen diluted $1: 1$ with physiological saline containing 500 i.u. of penicillin and $0.5 \mathrm{mg}$ of streptomycin $/ \mathrm{ml}$. The number of spermatozoa inseminated usually was far in excess of one million, which has been shown by many workers to be a sufficient number to give maximum fertility. The semen was deposited into the anterior portion of the vagina. The females were injected simultaneously with an ovulating dose of $2.5 \mathrm{mg}$ luteinizing hormone (Armour's PLH) at the time of insemination and allowed to kindle.

Testis size following treatment was monitored in vivo by measuring testicular length and width with callipers before each biopsy on the anaesthetized animals. From testis measurements made on intact animals and after testis removal, a regression equation was developed to calculate testis size in vivo. Statistical evaluation of treatment differences was done by the $t$ test.

\section{RESULTS}

Sperm output, motility and morphology in the controls were relatively uniform throughout the experimental period (Table 1, Text-fig. 1). Sperm output was reduced to less than half the original level 8 weeks after a single injection of $0.2 \mathrm{mg} \mathrm{TEM} / \mathrm{kg}$ bodyweight $(P<0.05)$. Twice this amount of TEM given to Group III males caused a greater depression by the 9th week (Text-fig. 1). Recovery proceeded at a rapid rate. Five injections of TEM (Group IV) reduced sperm output to minimal levels during the 9th to 14th weeks following administration. Gradual recovery followed. Cadmium treatment killed two of the rabbits although the dose was below the minimum lethal dose given by Cameron \& Foster (1963). Sperm output in the three survivors approached zero within 4 weeks $(P<0.01)$ and no evidence of recovery was found in semen collected during the 17-week experimental period.

Reduction in motility of spermatozoa paralleled sperm output, although the magnitude of the treatment effect on motility was less pronounced. The proportion of normal spermatozoa also decreased slightly during periods of low sperm output (Table 1). Shrunken heads and deformed acrosomes (Plate 1) were prevalent in Group IV 9 weeks after starting treatment with TEM. Also, there was a difference in the percentage of motile spermatozoa and normal spermatozoa between groups. This reflected differences between males assigned to the groups initially on the basis of sperm output only. 


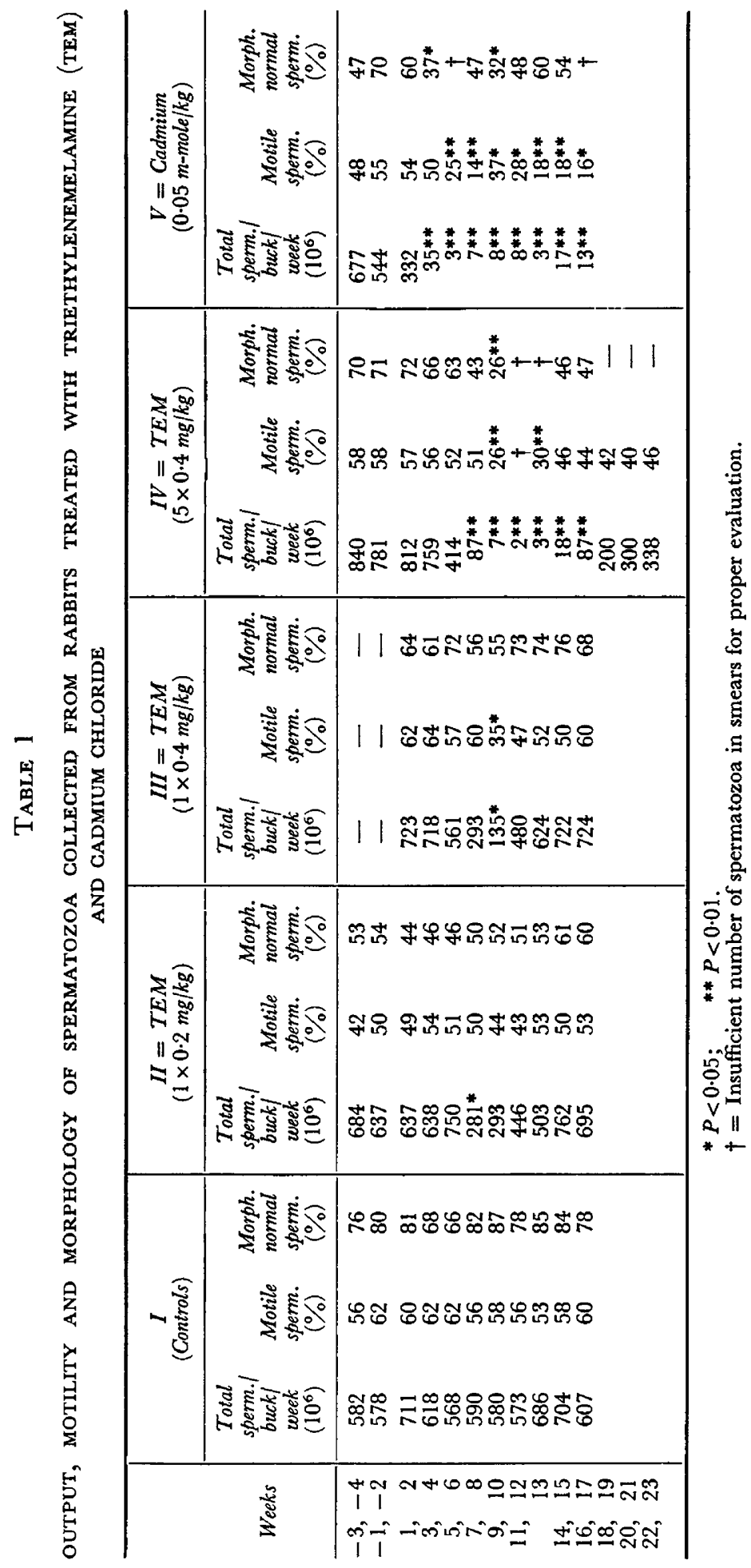


Testis size, shown in Table 2, was reduced $(P<0 \cdot 01)$ by the highest level of TEM (Group IV) and by cadmium. Whereas the testes of TEM-treated males recovered, there was no gross indication of this occurring following cadmium treatment.

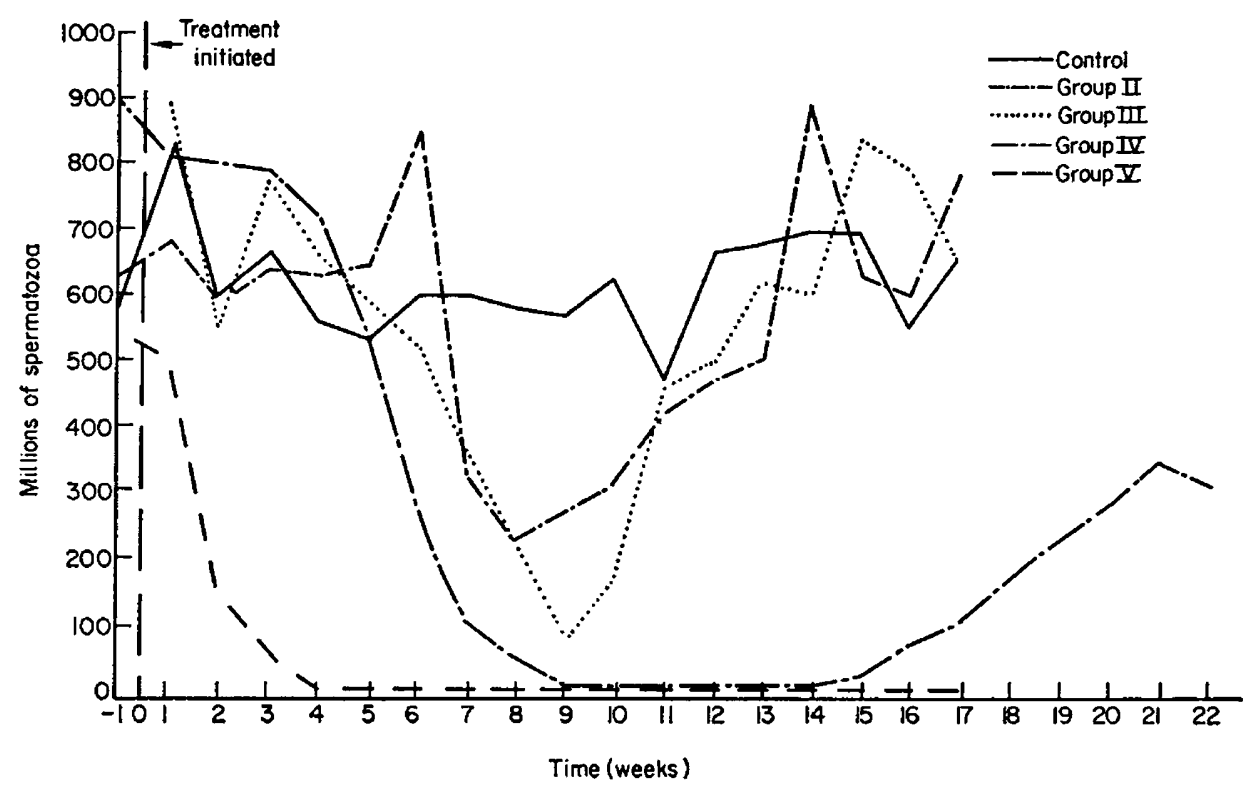

TExT-Fig. 1. Graph showing the depressing effect of TEM and cadmium on sperm output.

TABLE 2

CALGULATED TESTIS WEIGHT IN RABBitS TREATED WITH TRIETHYLENEMELAMINE (TEM) AND CADMIUM GHLORIDE

\begin{tabular}{c|c|c|c|c}
\hline & \multicolumn{4}{|c}{ Testis wt $(g) \dagger$} \\
\cline { 2 - 5 } $\begin{array}{c}\text { Weeks after } \\
\text { treatment }\end{array}$ & $\begin{array}{c}I \\
\text { (Controls) }\end{array}$ & $\begin{array}{c}I I \\
\text { (1) } 0.2 \mathrm{mg} \text { TEM })\end{array}$ & $\begin{array}{c}I V \\
(1 \times 0.4 \mathrm{mg} \text { TEM })\end{array}$ & $\begin{array}{c}\text { V } \\
(\text { Cadmium })\end{array}$ \\
\hline 1 & $2 \cdot 5$ & $2 \cdot 2$ & $2 \cdot 2$ & $1 \cdot 1^{* *}$ \\
5 & $2 \cdot 4$ & $2 \cdot 4$ & $1 \cdot 2^{* *}$ & $1 \cdot 1^{* *}$ \\
9 & $2 \cdot 3$ & $2 \cdot 4$ & $0.9^{* *}$ & $0 \cdot 7^{* *}$ \\
13 & $2 \cdot 4$ & $2 \cdot 3$ & $1 \cdot 1^{* *}$ & $0 \cdot 6^{* *}$ \\
17 & $2 \cdot 7$ & $2 \cdot 8$ & $1 \cdot 2^{* *}$ & $0 \cdot 5^{* *}$ \\
23 & - & - & $1 \cdot 9$ & - \\
\hline
\end{tabular}

** $P<0.01$.

$\dagger$ Assumes that the specific gravity of the testis was 1-0. Possible changes in specific gravity during atrophy could not be determined because the testis was sampled by biopsy.

Marked changes in the cell population of the testes following treatment are reflected by the proportional counts shown in Table 3 and the histological appearance shown in Plates 2 and 3. Within 1 week after injection of TEM, intermediate and type B spermatogonia had essentially disappeared, followed at 5 weeks by a reduction $(P<0 \cdot 01)$ in the proportion of primary spermatocytes 


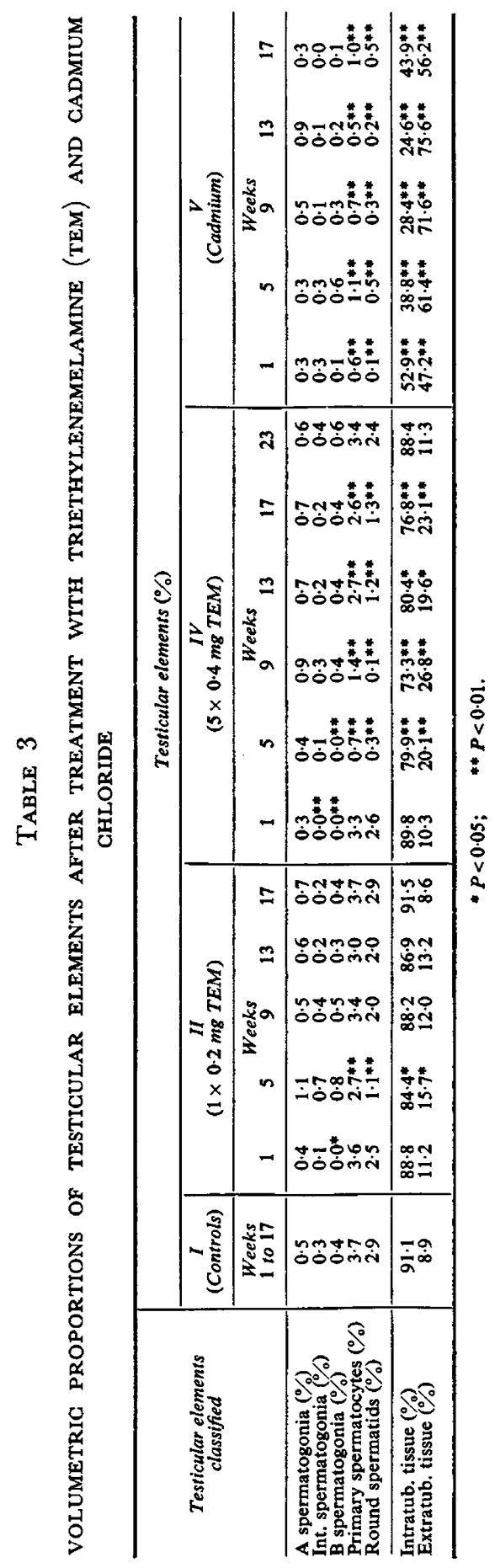




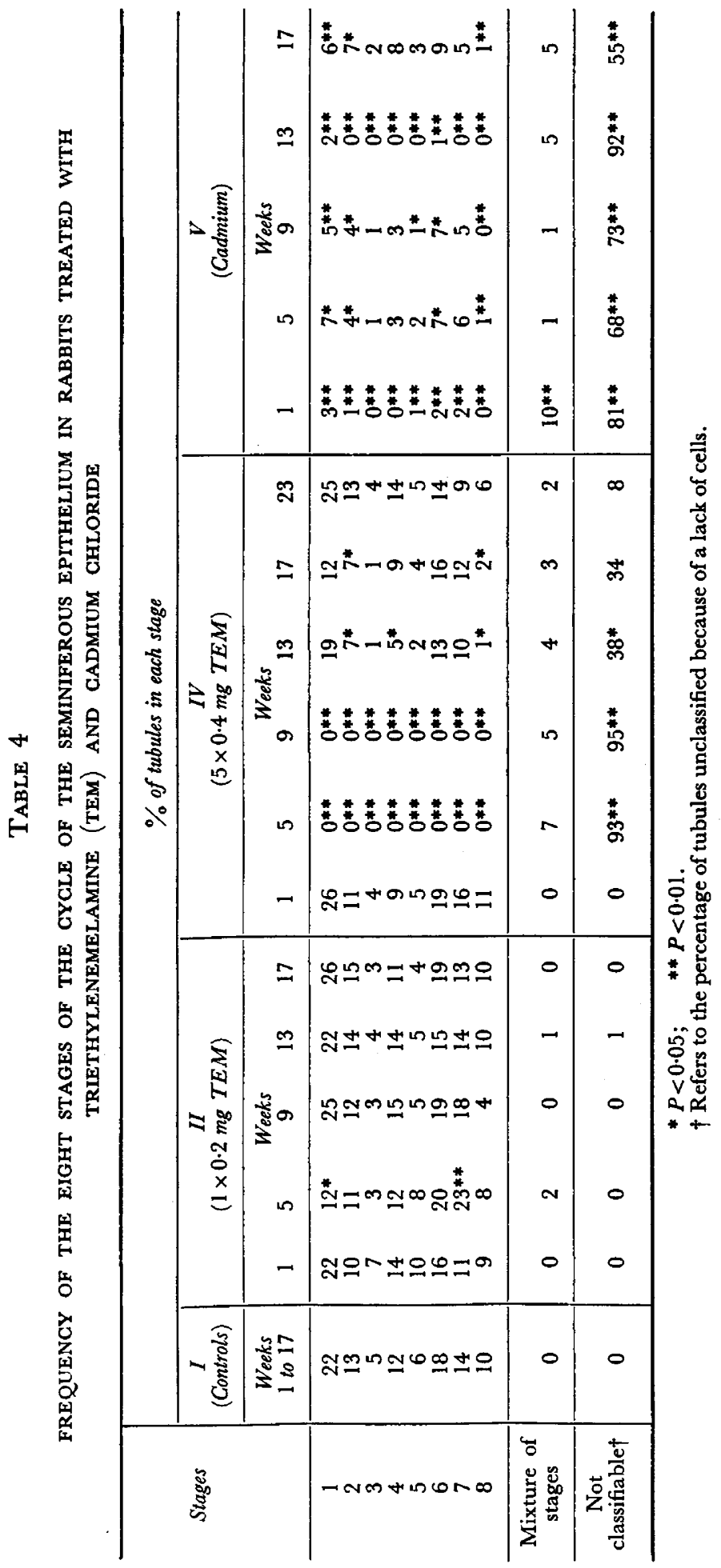


TABLE 5

MEAN DIAMETERS OF SEMINIFEROUS TUBULES OF RABBITS TREATED WITH TRIETHYLENEMELAMINE (TEM) AND CADMIUM GHLORIDE

\begin{tabular}{|c|c|c|c|c|}
\hline \multirow[b]{2}{*}{$\begin{array}{c}\text { Weeks after } \\
\text { treatment }\end{array}$} & \multicolumn{4}{|c|}{ Mean diameter of tubules $(\mu)$} \\
\hline & $\begin{array}{c}I \\
\text { (Controls) }\end{array}$ & $\begin{array}{c}I I \\
(1 \times 0.2 \mathrm{mg} T E M)\end{array}$ & $\begin{array}{c}I V \\
(5 \times 0.4 m g T E M)\end{array}$ & $\underset{(\text { Cadmium })}{V}$ \\
\hline $\begin{array}{r}1 \\
5 \\
9 \\
13 \\
17 \\
23\end{array}$ & $\begin{array}{l}203 \\
201 \\
198 \\
206 \\
201 \\
\end{array}$ & $\begin{array}{l}194 \\
171^{*} \\
190 \\
194 \\
193 \\
-\end{array}$ & $\begin{array}{l}199 \\
130^{* *} \\
122^{* *} \\
168^{* *} \\
149^{* *} \\
199\end{array}$ & $\begin{array}{r}132^{* *} \\
93^{* *} \\
71^{* *} \\
67^{* *} \\
132^{* *} \\
-\end{array}$ \\
\hline
\end{tabular}

TABLE 6

FERTILITY FOLLOWING TEM AND GADMIUM TREATMENT

\begin{tabular}{|c|c|c|c|c|c|}
\hline $\begin{array}{l}\text { Weeks after } \\
\text { treatment }\end{array}$ & Criteria & $\begin{array}{c}I \\
\text { (Controls) }\end{array}$ & $\begin{array}{c}I I=T E M \\
(1 \times 0.2 \mathrm{mg} / \mathrm{kg})\end{array}$ & $\begin{array}{c}I V=T E M \\
(5 \times 0.4 \mathrm{mg} / \mathrm{kg})\end{array}$ & $\underset{\text { (Cadmium) }}{V}$ \\
\hline 0 & $\begin{array}{l}\text { No. of does } \\
\text { No. kindled } \\
\text { Ave. litter size } \dagger\end{array}$ & $\begin{array}{l}11 \\
7 \\
3 \cdot 0\end{array}$ & $\begin{array}{l}10 \\
9 \\
4 \cdot 1\end{array}$ & $\begin{array}{c}14 \\
12 \\
5 \cdot 9\end{array}$ & $\begin{array}{l}6 \\
6 \\
6 \cdot 3\end{array}$ \\
\hline 1 to 2 & $\begin{array}{l}\text { No. of does } \\
\text { No. kindled } \\
\text { Ave. litter size }\end{array}$ & $\begin{array}{l}11 \\
10 \\
4 \cdot 6\end{array}$ & $\begin{array}{l}10 \\
6 \\
1.9 *\end{array}$ & $\begin{array}{l}12 \\
0 \\
0 \cdot 0 * *\end{array}$ & $\begin{array}{l}6 \\
1 \\
0 \cdot 5^{* *}\end{array}$ \\
\hline 3 to 5 & $\begin{array}{l}\text { No. of does } \\
\text { No. kindled } \\
\text { Ave. litter size }\end{array}$ & 二 & $\begin{array}{l}5 \\
5 \\
6 \cdot 2\end{array}$ & $\begin{array}{l}17 \\
0 \\
0 \cdot 0^{* *}\end{array}$ & 二 \\
\hline 6 to 8 & $\begin{array}{l}\text { No. of does } \\
\text { No. kindled } \\
\text { Ave. litter size }\end{array}$ & $\begin{array}{l}5 \\
4 \\
4 \cdot 0\end{array}$ & $\begin{array}{l}5 \\
5 \\
4 \cdot 8\end{array}$ & $\begin{array}{l}15 \\
1 \\
0 \cdot 1^{* *}\end{array}$ & $\begin{array}{l}2 \\
2 \\
2 \cdot 5\end{array}$ \\
\hline 9 to 11 & $\begin{array}{l}\text { No. of does } \\
\text { No. kindled } \\
\text { Ave, litter size }\end{array}$ & $\begin{array}{l}12 \\
12 \\
6 \cdot 4\end{array}$ & $\begin{array}{l}10 \\
9 \\
6 \cdot 2\end{array}$ & $\frac{\ddagger}{-}$ & $\begin{array}{l}6 \\
2 \\
2 \cdot 2\end{array}$ \\
\hline 12 to 14 & $\begin{array}{l}\text { No. of does } \\
\text { No. kindled } \\
\text { Ave. litter size }\end{array}$ & 二 & 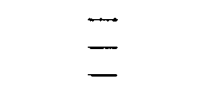 & $\begin{array}{l}11 \\
6 \\
3 \cdot 0\end{array}$ & 二 \\
\hline 15 to 16 & $\begin{array}{l}\text { No. of does } \\
\text { No. kindled } \\
\text { Ave. litter size }\end{array}$ & E & E & $\begin{array}{l}8 \\
7 \\
5 \cdot 6\end{array}$ & $\overline{-}$ \\
\hline Ave. & $\begin{array}{l}\text { No. of does } \\
\text { No. kindled } \\
\text { Ave. litter size }\end{array}$ & $\begin{array}{l}39 \\
33 \\
4 \cdot 6\end{array}$ & $\begin{array}{c}40 \\
34 \\
4 \cdot 4\end{array}$ & $\begin{array}{l}77 \\
26 \\
2 \cdot 0\end{array}$ & $\begin{array}{l}20 \\
11 \\
3.0\end{array}$ \\
\hline
\end{tabular}




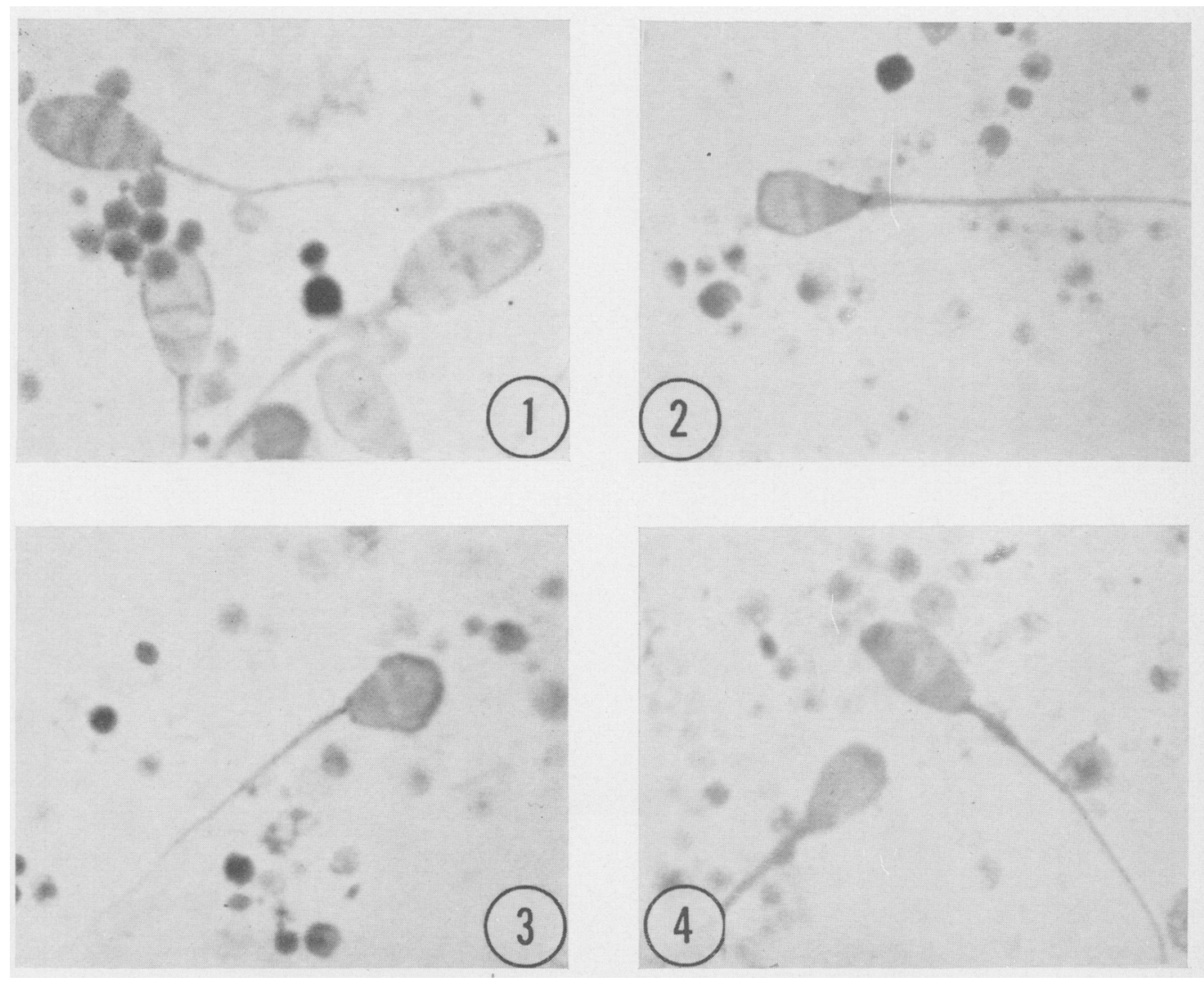

Spermatozoa stained with aniline blue-crystal violet. $\times 2000$.

Fig. 1. Control Group I. Normal spermatozoa and one giant cell, found occasionally in most animals, are shown.

FIGs. 2, 3 and 4 are spermatozoa 9 weeks after treatment with TEM in Group IV. Note the shrunken heads and deformed acrosomes. 
PI.X'I'?
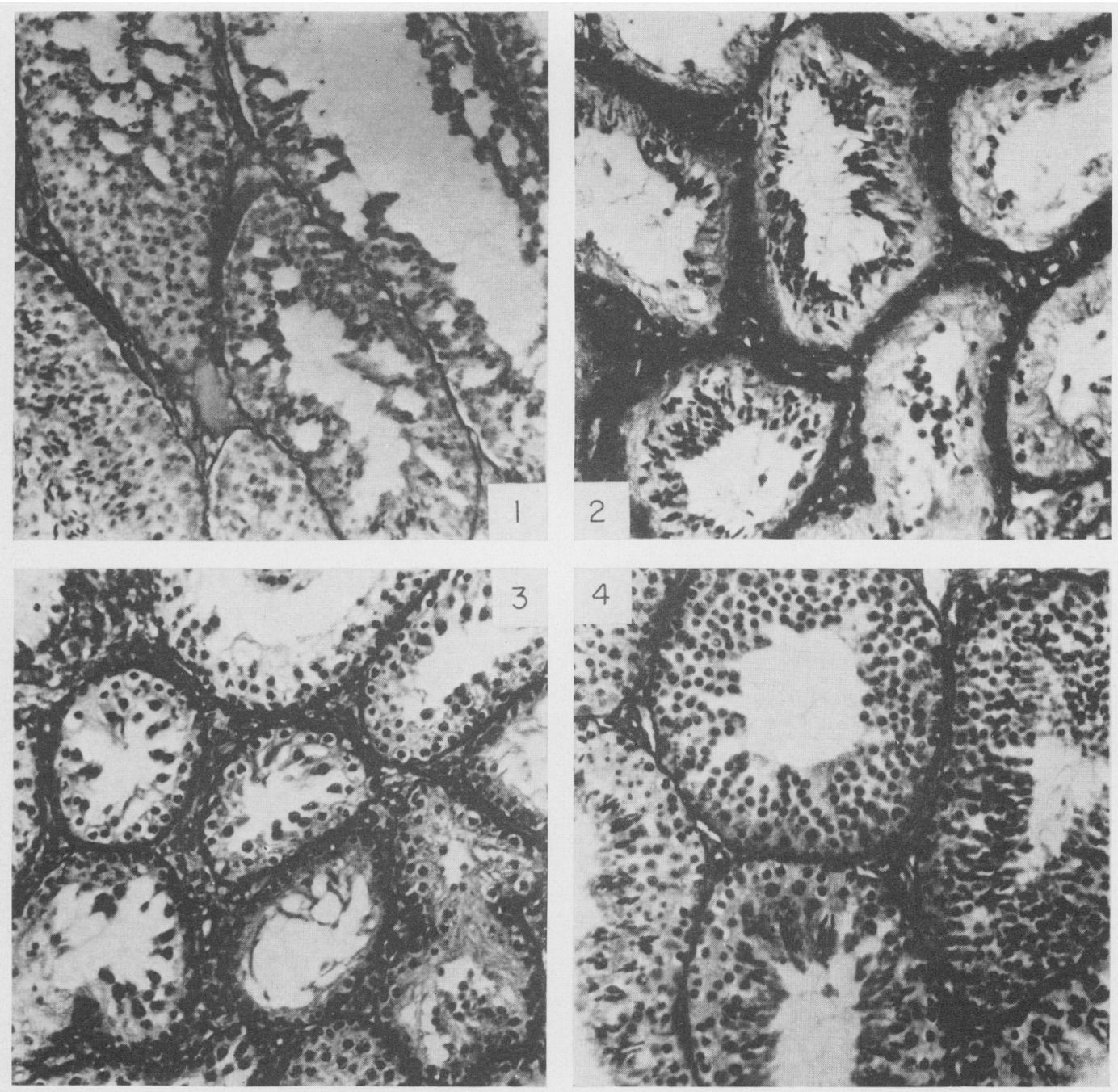

Sections of testes from rabbits trated with TliS in Group IV. Stained with PAS hatematoxylin. $\times 190$.

Fre. 1. (One werk after the first injection. extensive destruction of spermatogenic cells is evident.

Fifi.2. Five weeks after the first injection. extensive destruction has occurred in most tubules, but not all tubules show equal damage.

lici. 3. Thirteen weeks after the lirst injection. slight regeneration has started in many tubules.

lin. 4. Twenty-thee weeks after the first injection, lubules show active spermatogenesis. 

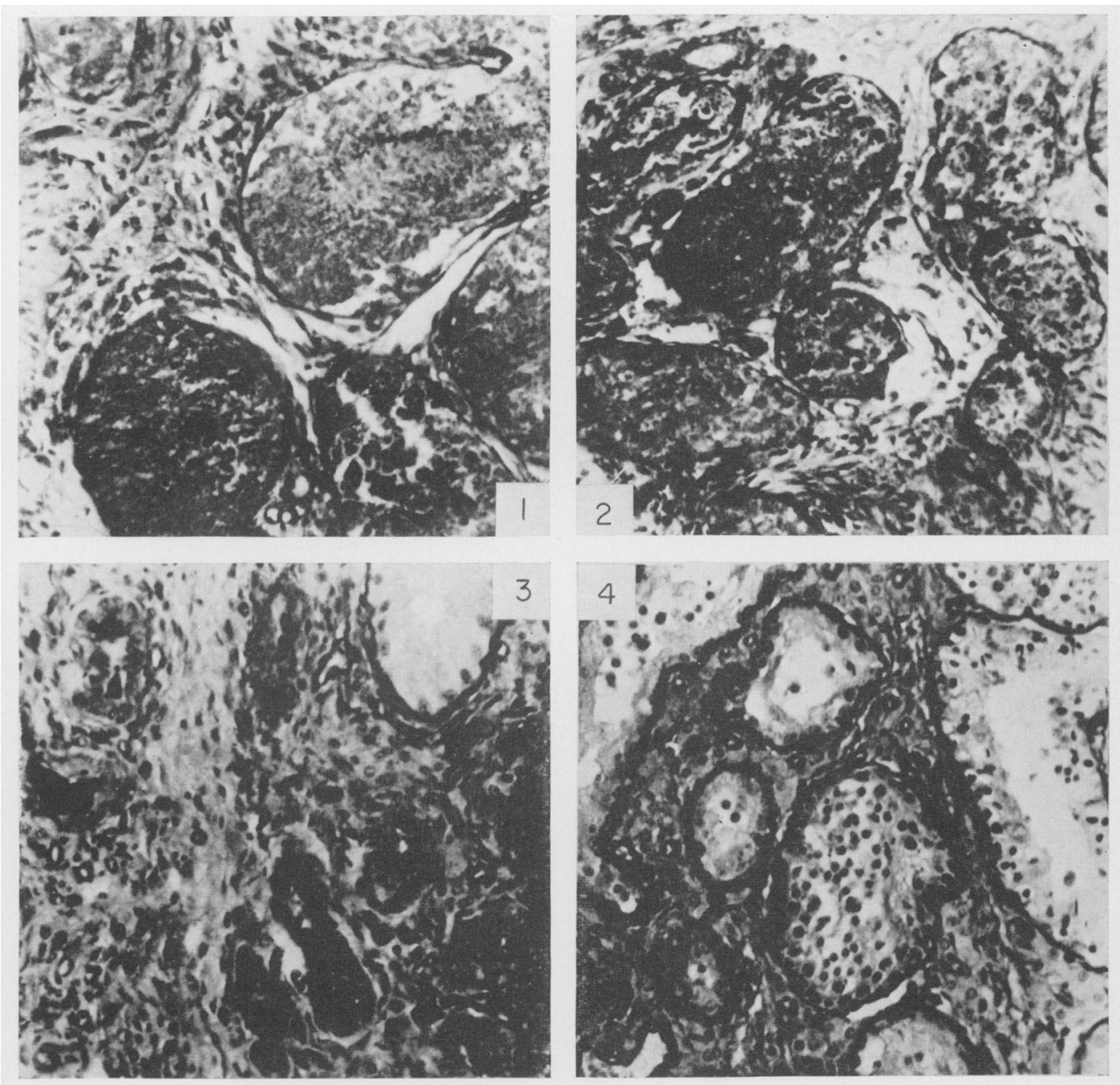

Sections of testes from rabbits treated with admium chloride $\times 190$.

Fics. 1, 2. 3 and 4 . Sections taken $1,5.9$ and 17 weeks. respectively, after treament show shrinkige and disorganization of lubules with a vase increase proportionately in the interstitium. Pyonotic nuclei. extravasated blood and nuclear debris are erident. 
and round spermatids. These changes were reversible. At the end of the experiment spermatogenesis appeared to be normal (Plate 2), and the testicular cell population had returned to control levels. Cadmium markedly reduced the spermatocytes and round spermatids throughout the experiment $(P<0 \cdot 01)$, but had less of an effect upon the spermatogonia. The proportion of tubular tissue was markedly decreased, but there was a suggestion of some regeneration by the 17 th week (Table 3 ). These histological changes are shown in Plate 3.

The overall pattern of spermatogenesis is best revealed by classification of the tubules into eight stages. These results are summarized in Table 4. Males in Group II had fewer tubules in Stage 1 and more in Stage 7 at 5 weeks after treatment. The major changes were found at the highest level of TEM treatment and in Group V receiving cadmium. Most tubules in these groups were, shortly after treatment, devoid of cells required for classification. The proportion of classifiable tubules showing completion of spermatogenesis (Stage 8) was very low $(P<0 \cdot 01)$.

Sloughing of the elements of the seminiferous epithelium was accompanied by shrinkage of the seminiferous tubules. The degree of shrinkage and its statistical significance is shown in Table 5 .

The fertilizing capacity of control and treated males was tested at frequent intervals (Table 6). Fertility was significantly reduced $(P<0 \cdot 05)$ in Group II during the first 2 weeks after injection despite the use of what appeared to be high quality normal semen. At the higher level of TEM, essentially no fertilization resulted from the weekly insemination of semen during the first 8 weeks following initiation of treatment. There were insufficient spermatozoa for insemination during Weeks 9 to 12; fertility was regained by the 13th week. Cadmium-treated males, on the other hand, appeared to retain some fertilizing capacity throughout the experiment despite a minimum number of spermatozoa available for insemination.

Examination of young born in all treatments revealed no anomalies.

\section{DISCUSSION}

Both TEM and cadmium effectively interfered with spermatogenesis, but the resultant damage and mechanisms involved appeared to differ. Cadmium caused a severe necrosis (Plate 3), which was associated with haemorrhage and damage to the vascular supply. These changes have been observed previously in the rat (Paŕizek, 1960; Gunn et al., 1963, 1965), and in the rabbit (Cameron \& Foster, 1963). The extensive destruction of the tubular elements in Group V was associated with shrinkage of the testis and oligospermia. The increase in the proportion of extra-tubular components (Table 3) is greater than the proportional decrease in testicular size (Table 2), suggesting an actual increase in extra-tubular components. Little repair was evident during the 17 weeks following cadmium treatment, but some spermatogenic cells remained. Reduced fertilizing capacity was associated with the marked decrease in sperm output; complete sterility did not occur (Table 6), indicating that cadmium was not blocking the fertility of the sperm cells produced.

All effects of TEM observed in the testis appeared to be connected with its 
well-known inhibitory effect on cell multiplication. TEM severely affected intermediate and type B spermatogonia. The reduction in these spermatogonial cells led to a subsequent decrease in spermatocytes and spermatids. Spermatogonial type A cells showed no effect of TEM treatment, indicating that they are less susceptible to this alkylating agent. These findings are in agreement with work on mice and rats (Bock \& Jackson, 1957; Cattanach \& Edwards, 1958; Bateman, 1960). Fox et al. (1963) suggested that spermatogonia in rabbits were affected, but histological studies were not reported. Based upon the time required for spermatogenesis and sperm transport (Swierstra \& Foote, 1965), one would expect a decrease in sperm output to begin about 6 weeks later when epididymal reserves are depleted by frequent semen collection. This corresponds to sperm output results presented in Text-fig. 1. With less frequent ejaculation the interval may be longer (Fox et al., 1963). Since the prevalence of abnormal sperm cells in ejaculated semen did not occur until after this time, it appears that the spermatocytes and spermatids already formed at the time of TEM injection proceeded to develop normally. The same types of abnormality have been noted to occur with lower frequency in normal rabbits (Onuma \& Otsuki, 1966). Animals in Group IV became sterile within 1 week after treatment. Since epididymal transport takes more than 1 week, this finding suggests that the function of epididymal spermatozoa, classified morphologically as normal, was in fact impaired.

The possible effect of TEM carried in the sperm cell on early cleavage of the fertilized eggs was not investigated. All new-born young, however, appeared to be normal so no gross teratogenic effects were induced in the immediate progeny.

\section{ACKNOWLEDGMENTS}

This study was supported in part by Public Health Service Research Grant GM10263 from the National Institute of General Medical Sciences, and by the Population Council. The authors are grateful to Dr H. Jackson for supplying some of the TEM used in their experiments and to Dr John Whitefield and Dr L. D. VanVleck for technical assistance.

\section{REFERENCES}

Bateman, A. J. (1960) The induction of dominant lethal mutations in rats and mice with TEM. Genet. Res. 1, 381.

Bock, M. \& JAckson, H. (1957) The action of triethylenemelamine on the fertility of male rats. Br. $\mathcal{J}$. Pharmac. Chemother. 12, 1.

Bredderman, P.J., Foote, R. H. \& Yassen, A. M. (1964) An improved artificial vagina for collecting rabbit semen. 7. Reprod. Fert. 7, 401.

Cameron, E. \& Foster, C. L. (1963) Observations on the histological effects of sub-lethal doses of cadmium chloride in the rabbit. I. The effect on the testis. F. Anat. 97, 269.

Cattanach, B. M. (1959) The sensitivity of the mouse testis to the mutagenic action of TEM. $Z$. VererbLehre. 90, 1 .

Cattanach, B. M. \& Edwards, R. G. (1958) The effects of TEM on the fertility of male mice. Proc. R. Soc. Edinb. B, 67, 54 .

Chalkzey, H. W. (1943) Method for the quantitative morphologic analysis of tissues. $\mathcal{F}$. natn. Cancer Inst. 4, 47.

Chrouorne, A. D. (1964) Observations on the early events of cadmium necrosis of the testis. Anat. Rec. $149,23$. 
Foote, R. H. (1964) Sperm losses from semen collection to insemination. Vth Int. Congr, Anim. Reprod. Artif. Insem. 4, 416.

Foote, R. H. \& Koefoed-Johnsen, H. H. (1959) The use of adenine-8-C ${ }^{14}$ for studying spermatogenesis in the rabbit, F. Anim. Sci. 18, 1553.

Fox, B. W., Jackson, H., CRaig, A. W. \& Glover, T. D. (1963) Effects of alkylating agents on spermatogenesis in the rabbit. J. Reprod. Fert. 5, 13.

Gunn, S. A., Gould, T. C. \& Anderson, W. A. D. (1963) The selective injurious response of testicular and epididymal blood vessels to cadmium and its prevention by zinc. Am. F. Path. 42, 685 .

Gunn, S. A., Gould, T. C. \& Anderson, W. A. D. (1965) Strain differences in susceptibility of mice and rats to cadmium-induced testicular damage. F. Reprod. Fert. 10, 273.

Hampel, K. E. \& Gerhartz, H. (1965) Strukturanomalien der Chromosomen menschlicher Leukozyten in vitro durch Triethylenmelamin. Expl Cell Res. 37, 251.

JAckson, H. \& Bock, M. (1955) The effect of triethylenemelamine on the fertility of rats. Nature, Lond. $175,1037$.

Kennelly, J. J. \& Foote, R. H. (1964) Sampling boar testes to study spermatogenesis quantitatively and to predict sperm production. F. Anim. Sci. 23, 160.

Mason, K. E., Brown, J. A., Young, J. O. \& Nesbit, R. R. (1964) Cadmium-induced injury of the rat testis. Anat. Rec. 149, 135.

Onuma, H. \& Otsuki, K. (1966) A simple method for counting abnormal spermatozoa of bulls, boars and rabbits with a phase contrast microscope. Jap. F. Anim. Reprod. 12, 95.

PAর̌ízek, J. (1960) Sterilization of the male by cadmium salts. F. Reprod. Fert. 1, 294.

Steingerger, E., Nelson, W. O., Boccabella, A. \& Dixon, W. J. (1959) A radiomimetic effect of triethylenemelamine on reproduction in the male rat. Endocrinology, 65, 40.

SWIERSTRA, E. E. (1962) The cytology and kinetics of spermatogenesis in the rabbit, and the desoxyribonucleic acid content of spermatogenic cells. Ph.D. thesis, Cornell University, Ithaca, N.Y.

Swierstra, E. E. \& Foote, R. H. (1963) The cytology and kinetics of spermatogenesis in the rabbit. 7. Reprod. Fert. 5, 309.

Swierstra, E. E. \& Foote, R. H. (1965) Duration of spermatogenesis and spermatozoan transport in the rabbit based on cytological changes, DNA synthesis and labeling with tritiated thymidine. Am. F. Anat. 116, 401. 